\title{
Научная компонента селекции (по вопросам, поднятым в спецвыпуске «Вавиловского журнала генетики и селекции», 2021, Т. 25, № 4)
}

\section{В.И. Глазко凶}

Для цитирования: Глазко В.И. Научная компонента селекции (по вопросам, поднятым в спецвыпуске «Вавиловского журнала генетики и селекции», 2021, T. 25, № 4). Письма в Вавиловский журнал генетики и селекции. 2021;7(4):201-205. DOI 10.18699/LettersVJ2021-7-25 of Genetics and Breeding, 2021;25(4)

\section{V.I. Glazko凶}

For citation: Glazko V.I. The scientific component of breeding: questions raised in the special issue of the Vavilov Journal of Genetics and Breeding, 2021;25(4). Pisma v Vavilovskii Zhurnal Genetiki i Selektsii = Letters to Vavilov Journal of Genetics and Breeding. 2021;7(4):201-205. DOI 10.18699/ LettersVJ2021-7-25 (in Russian)

Посмотрев спецвыпуск «Вавиловского журнала генетики и селекции» (2021, Т. 25, № 4), посвященный современному состоянию селекции растений в РФ, хотел бы сделать несколько замечаний, - сугубо основанных на моем частном опыте и сложившемся мнении. Бесконечно согласен с положениями и утверждением о том, что основа государственной безопасности РФ лежит в организации и ведении сельского хозяйства, в частности в растениеводстве, изложенными в предисловии к выпуску (Гончаров, Косолапов, 2021) и статье Н.П. Гончарова (2021). И что нет не только стратегии, но и научно обоснованных тактических решений. Понятно, что, к сожалению, все это определяется отсутствием достаточного вклада научного сообщества, деградация которого обнаруживается не только в нашем отечестве, но отражает глобальные мировые тенденции. Важно также отметить и то, что состояние нашего научного сообщества определяется еще и тем фактом, что тридцать лет назад плановая эко- номика проиграла рыночной, не заметив, что рыночная основана на рекламе, причем наукоемкой. С чем плановая экономика фактически не была знакома. Естественно, ее, как и научное сообщество, легко можно было убедить в том, что они - второго сорта. Именно с тех пор большое количество научных подразделений работает как «бюро перевода» англоязычных статей на русский язык, и новизна исследований определяется новизной - объектов...

Н.П. Гончаров (2021) четко формулирует проблему и прямо указывает адреса государственных структур и необходимые изменения, которые они должны принять, - с целью улучшения ситуации с фундаментальными проблемами той части аграрной цивилизации, которая локализована на территории России.

Хотелось бы изложить несколько моих соображений по поводу селекции и направлений ее ускорения. Прежде всего мы должны определиться со стратегией развития раз- 


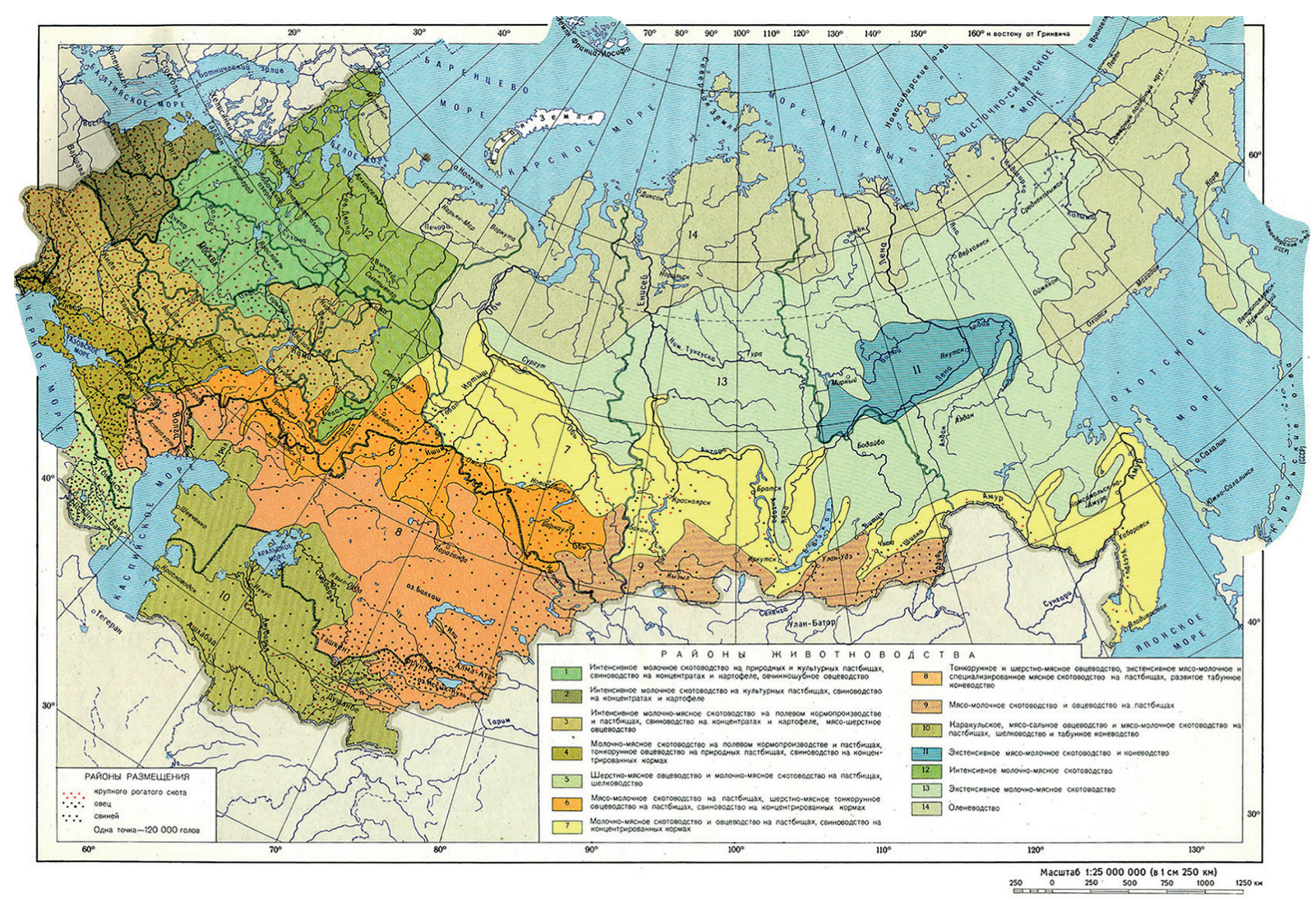

Рис. 1. Распределение систем производства животноводческой продукции на территории РФ (из: Географический атлас..., 1985)

личных направлений селекционной работы и обязательной ее адресностью. В качестве объяснения моей позиции хотел бы привести две иллюстрации. Одна - это области высокозатратного и пастбищного животноводства на территории России (рис. 1).

Легко увидеть, что первое сосредоточено в основном до Урала, второе - за ним, за исключением областей вокруг городов-миллионников. Понятно, что некоторые продукты научных разработок в области селекции, полученные в условиях высокозатратных животноводческих структур в «развитых странах», пытаются внедрить на всей территории РФ, что само по себе отражает непонимание отечественного разнообразия сельскохозяйственных систем. Вторая это распространенность пастбищного животноводства в разных странах (рис. 2). В ней наглядно демонстрируется важность пастбищного скотоводства именно для России.

Из этого следует, что в каждом конкретном регионе рентабельность сельскохозяйственной работы будет иметь свои специфические ограничения. Они будут обусловлены разными факторами: в одном случае - климатом и почвами, в другом - логистикой или уровнями загрязнения. В конечном счете любые проблемы селекции сводятся к четырем направлениям - продуктивность, адаптивность, воспроизводство и сохранение биоразнообразия. В конкретных локалитетах будет преобладать своя компонента. В этой связи очевидно, что должно быть подразделение направлений исследований, а именно: разработка инструментов выявления мишеней - факторов естественного и искусственного отборов, основанных на методах управления генетическими потоками в конкретных условиях воспроизводства сельскохозяйственных видов.

Пангеномика - очень важное направление, но оно никогда не будет успешной основой производства конкретных сортов культурных растений или пород животных просто потому, что фенотипические характеристики являются результатом взаимодействия слишком большого количества факторов и метагенома в том числе (рис. 3).

Прямая проекция фенотипических характеристик на пангеном невозможна еще и потому, что не существует прямых связей между продуктами структурных генов - протеомом и фенотипом, что хорошо иллюстрируется теми же авторами при сопоставлении между белковыми сетями и продуктами метаболизма, влияющими на работу этих сетей (рис. 4).

В чем пангеномика всегда будет иметь лидирующее значение - это, как ни странно, в основном, в трех направлениях: выявление аллельных вариантов структурных генов и элементов регуляторных сетей, которые служат мишенями факторов естественного отбора (см. работы Дениса Ларкина и другие по экологической геномике у сельскохозяй- 


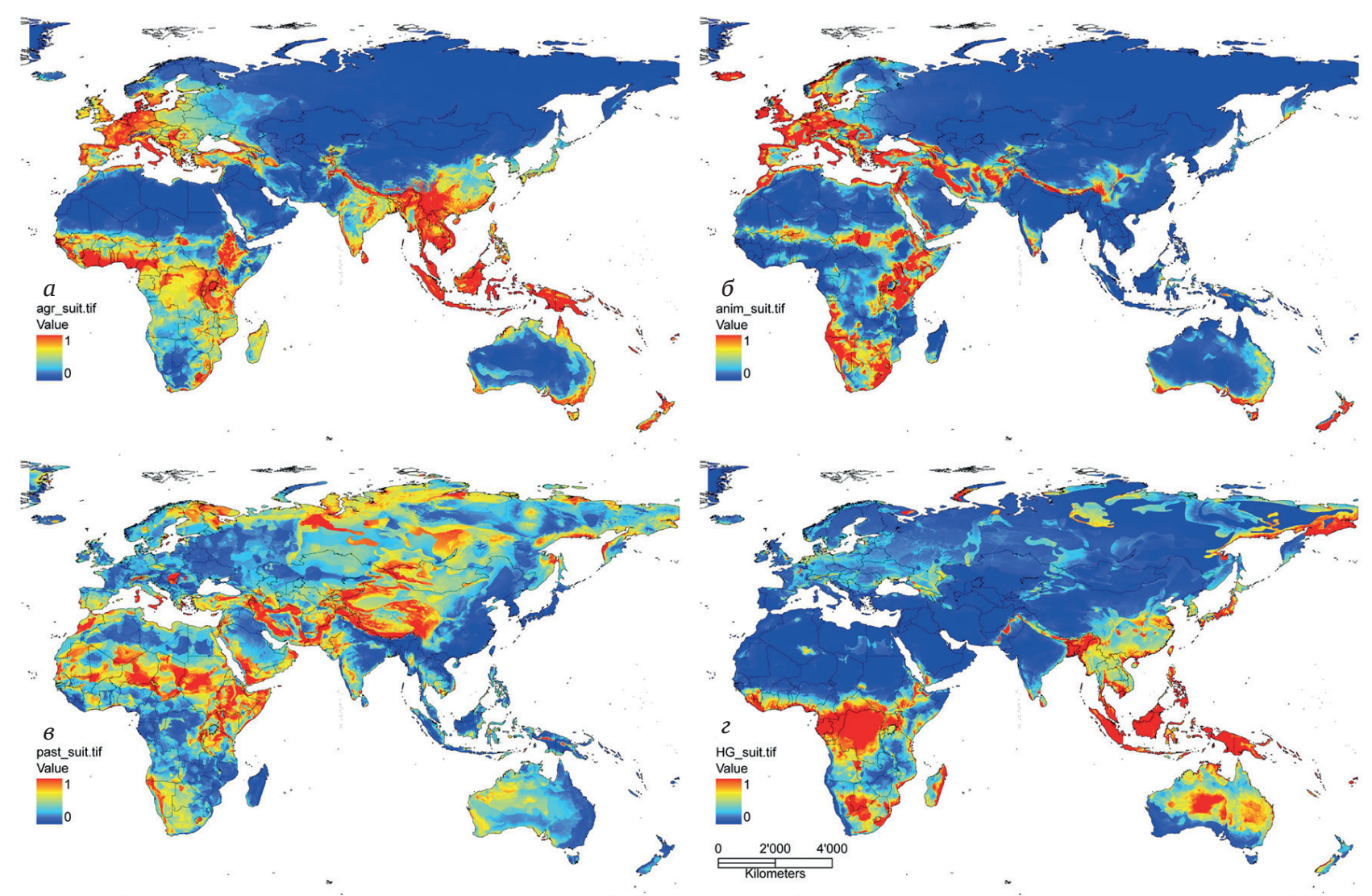

Рис. 2. Зависимость различных типов хозяйствования, и на 40\% вклад в ВВП определяется только двумя параметрами - почвой и климатом (из: Beck, Sieber, 2010)

$a$ - смешанное сельское хозяйство, 6 - оседлое животноводство, в - пастбищное скотоводство, г - охота и собирательство

G $\quad+\quad$ E $\quad+\quad$ GE $\quad \rightarrow \quad$ P

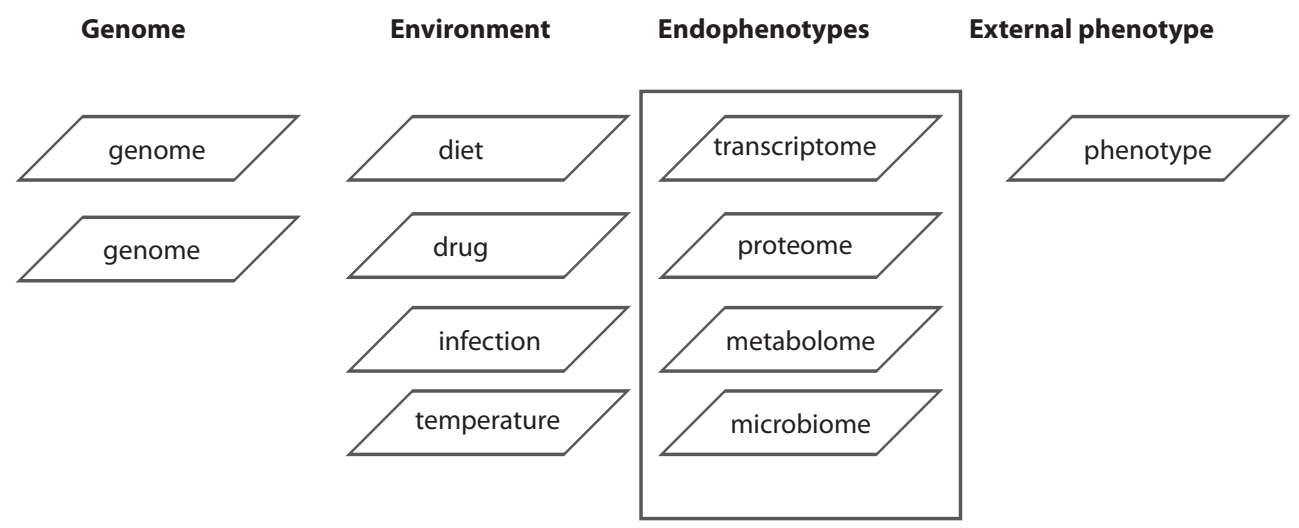

Рис. 3. Генотип и среда меняют эндофенотип животных, и вместе они меняют экзофенотип (из: Te Pas et al., 2017) 


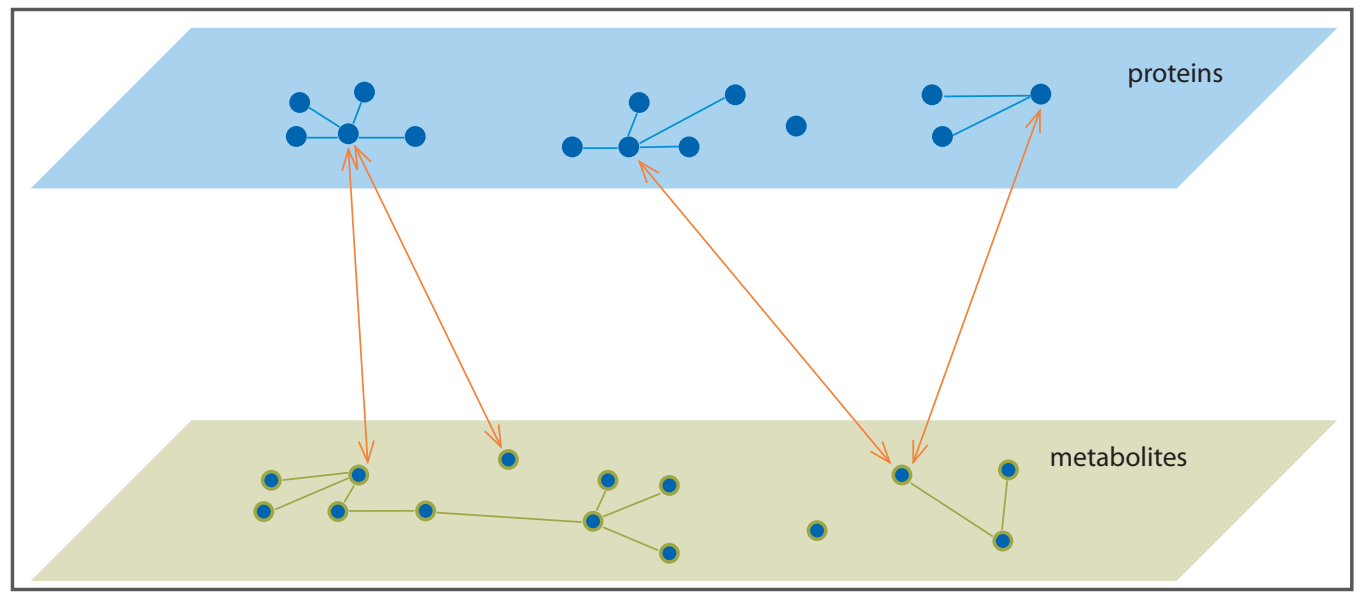

Рис. 4. Взаимодействия между элементами одного уровня организации биологических объектов (белки) и элементами другого уровня (метаболиты) (из: Te Pas et al., 2017)

ственных видов животных, например, Юдин, Ларкин, 2019; Yurchenko et al., 2019; Юдин и др., 2021; Sweet-Jones et al., 2021); накопление данных о неблагоприятных мононуклеотидных (SNP) рецессивных мутациях (потеря функции - Loss of Function (Cai et al, 2019), или, как называют на русском такие мутации, - «гаплотипы фертильности» (Зиновьева, 2016)); организация и смена программ генной экспрессии (работы Ирины Соловей по архитектонике интерфазного ядра, например (Feodorova et al., 2019)).

Эти направления позволяют выявить конкретные биомаркеры, контроль которых может способствовать увеличению успешности селекционной работы. В то же время нельзя преувеличивать значение пангеномики в решении традиционных вопросов селекционной работы особенно сейчас, в условиях быстрых изменений факторов окружающей среды.

Один из элементов противоречий между фундаментальными исследованиями и прикладными применениями полученных данных и заключается в том, что частные результаты первых быстро становятся модными и их пытаются выдать за универсальные. С этой точки зрения особую важность приобретает комплексный подход к каждой проблеме по усовершенствованию селекционной работы с конкретным генофондом и для конкретных условий и поиск ее конкретного адреса. Понятно, что в этой связи на меня самое большое впечатление среди очевидно добротных и интересных работ всего выпуска произвела статья В.М. Косолапова, В.И. Чернявских, С.И. Костенко (2021) и именно потому, что для начала они выполнили принципиально важную для стратегии развития современной селекции и семеноводства кормовых культур в России «ориентацию на местности», привязку к конкретным особенностям различных локалитетов России.

В свое время создатель аграрной экономики как науки А.В. Чаянов утверждал, что главная роль получения высшего аграрного образования заключается в том, что позволяет быть создателем и посредником между современными на- учными достижениями и их внедрением в конкретное производство сельскохозяйственной продукции. Очевидно, что именно эта функция наиболее «заброшена» в отечественном сельском хозяйстве. Полагаю, что вышедший специальный выпуск по селекции растений «Вавиловского журнала генетики и селекции» в определенной степени поможет, по крайней мере, зафиксировать эту проблему и стать основой для ее решения.

\section{Список литературы / References}

Географический атлас: для учителей сред. школы / отв. ред. Л.Н. Колосова, В.С. Чудинова. 4-е изд.; испр. М.: ГУГК, 1985.

[Geographical Atlas: for teachers of middle schools / Eds L.N. Kolosova, V.S. Chudinova. 4th edn; revised. Moscow: MDGM, 1985. (in Russian)]

Гончаров Н.П. Научное обеспечение селекции и семеноводства Сибири в XXI веке. Вавиловский журнал генетики и селекции. 2021;25(4):448-459. DOI 10.18699/VJ21.050.

[Goncharov N.P. Scientific support to plant breeding and seed production in Siberia in the XXI century. Vavilovskii Zhurnal Genetiki i Selektsii = Vavilov Journal of Genetics and Breeding. 2021;25(4):448-459. DOI 10.18699/VJ21.050.]

Гончаров Н.П., Косолапов В.М. Селекция растений - основа продовольственной безопасности России. Вавиловский журнал генетики и селекции. 2021;25(4):361-366. DOI 10.18699/VJ21.039.

[Goncharov N.P., Kosolapov V.M. Plant breeding is the food security basis in the Russian Federation. Vavilovskii Zhurnal Genetiki i Selektsii = Vavilov Journal of Genetics and Breeding. 2021;25(4):361-366. DOI 10.18699/VJ21.039.

Зиновьева Н.А. Гаплотипы фертильности голштинского скота. С.-х. биология. 2016;51(4):423-435. DOI 10.15389/agrobiology.2016.4.423rus.

[Zinovieva N.A. Haplotypes affecting fertility in Holstein cattle. Sel'skokhozyaistvennaya Biologiya = Agricultural Biology. 2016; 51(4):423-435. DOI 10.15389/agrobiology.2016.4.423eng.]

Косолапов В.М., Чернявских В.И., Костенко С.И. Развитие современной селекции и семеноводства кормовых культур в России. Вавиловский журнал генетики и селекции. 2021;25(4):401-407. DOI 10.18699/VJ21.044.

[Kosolapov V.M., Chernyavskih V.I., Kostenko S.I. Fundamentals for forage crop breeding and seed production in Russia. Vavilovskii Zhurnal Genetiki i Selektsii = Vavilov Journal of Genetics and Breeding. 2021;25(4):401-407. DOI 10.18699/VJ21.044.] 
Юдин Н.С., Ларкин Д.М. Общие признаки селекции и гены, связанные с адаптацией и акклиматизацией, в геномах российских пород крупного рогатого скота и овец. Генетика. 2019;55(8):936 943. DOI 10.1134/S0016675819070154.

[Yudin N., Larkin D.M. Shared signatures of selection related to adaptation and acclimation in local cattle and sheep breeds from Russia. Russ J Genet. 2019;55(8):1008-1014. DOI 10.1134/ S1022795419070159.]

Юдин Н.С., Юрченко А.А., Ларкин Д.М. Следы отбора и гены-кандидаты адаптации к экстремальным факторам среды в геномах ту рано-монгольских пород крупного рогатого скота. Вавиловский журнал генетики и селекции. 2021;25(2):190-201. DOI 10.18699/ VJ21.023.

[Yudin N.S., Yurchenko A.A., Larkin D.M. Signatures of selection and candidate genes for adaptation to extreme environmental factors in the genomes of Turano-Mongolian cattle breeds. Vavilovskii Zhurnal Genetiki $i$ Selektsii = Vavilov journal of genetics and breeding. 2021;25(2):190-201. DOI 10.18699/VJ21.023.]

Beck J., Sieber A. Is the Spatial Distribution of Mankind's Most Basic Economic Traits Determined by Climate and Soil Alone? PLOS ONE. 2010;5(5):E10416. DOI 10.1371/journal.pone.0010416.
Cai Z., Guldbrandtsen B., Lund M.S., Sahana G. Prioritizing candidate genes for fertility in dairy cows using gene-based analysis, functional annotation and differential gene expression. BMC Genomics. 2019;20(1):255. DOI 10.1186/s12864-019-5638-9.

Feodorova Y., Falk M., Mirny L.A., Solovei I. Viewing Nuclear Architecture through the Eyes of Nocturnal Mammals. Trends Cell Biol. 2020;30(4):276-289. DOI 10.1016/j.tcb.2019.12.008.

Sweet-Jones J., Lenis V.P., Yurchenko A.A., Yudin N.S., Swain M., Larkin D.M. Genotyping and Whole-Genome Resequencing of Welsh Sheep Breeds Reveal Candidate Genes and Variants for Adaptation to Local Environment and Socioeconomic Traits. Front Genet. 2021;12:612492. DOI 10.3389/fgene.2021.612492.

Te Pas M.F., Madsen O., Calus M.P., Smits M.A.The Importance of Endophenotypes to Evaluate the Relationship between Genotype and External Phenotype. Int J Mol Sci. 2017;18(2):472. DOI 10.3390/ijms18020472. Yurchenko A.A., Deniskova T.E., Yudin N.S., Dotsev A.V., Khamiruev T.N., Selionova M.I., Egorov S.V., Reyer H., Wimmers K., Brem G., Zinovieva N.A., Larkin D.M. High-density genotyping reveals signatures of selection related to acclimation and economically important traits in 15 local sheep breeds from Russia. BMC Genomics. 2019; 20(Suppl. 3):294. DOI 10.1186/s12864-019-5537-0.

Конфликт интересов. Автор заявляет об отсутствии конфликта интересов.

Поступила в редакцию 16.07.2021. После доработки 24.10.2021. Принята к публикации 25.10.2021. 